\title{
Thermal Characteristics, Mechanical Properties, In Vitro Degradation and Cytotoxicity of Novel Biodegradable $\mathrm{Zn}-\mathrm{Al}-\mathrm{Mg}$ and $\mathrm{Zn}-\mathrm{Al}-\mathrm{Mg}-\boldsymbol{x B i}$ Alloys
}

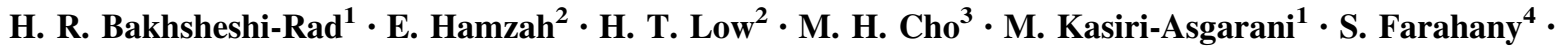 \\ A. Mostafa 5 - Medraj,
}

Received: 8 September 2016/Revised: 29 November 2016/Published online: 15 February 2017

(c) The Chinese Society for Metals and Springer-Verlag Berlin Heidelberg 2017

\begin{abstract}
Ternary $\mathrm{Zn}-0.5 \mathrm{Al}-0.5 \mathrm{Mg}$ and quaternary $\mathrm{Zn}-0.5 \mathrm{Al}-0.5 \mathrm{Mg}-x \mathrm{Bi}(x=0.1,0.3$ and 0.5$)$ alloys were studied to evaluate the thermal and structural characteristics, mechanical properties, cytotoxicity and in vitro degradation behavior. Thermal analysis and microstructural observations showed that $\mathrm{Zn}-0.5 \mathrm{Al}-0.5 \mathrm{Mg}$ is composed of $\mathrm{FCC}-\mathrm{Al}+\mathrm{HCP}-$ $\mathrm{Zn}+\mathrm{Mg}_{2}(\mathrm{Zn}, \mathrm{Al})_{11}$ while a new phase $\alpha-\mathrm{Mg}_{3} \mathrm{Bi}_{2}$ appeared after the addition of Bi to the $\mathrm{Zn}-0.5 \mathrm{Al}-0.5 \mathrm{Mg}$ ternary alloy. The results revealed that the quaternary $\mathrm{Zn}-\mathrm{Al}-\mathrm{Mg}-\mathrm{Bi}$ alloys have higher tensile strength, elongation and hardness but slightly lower corrosion resistance than those of the ternary $\mathrm{Zn}-\mathrm{Al}-\mathrm{Mg}$ alloy. Based on the MTT assay, the $\mathrm{Zn}-\mathrm{Al}-\mathrm{Mg}$ and $\mathrm{Zn}-\mathrm{Al}-\mathrm{Mg}-\mathrm{Bi}$ alloys were found to be biocompatible, and thus, they can be considered for further investigation in an in vivo environment.
\end{abstract}

KEY WORDS: Zn-Al-Mg-Bi; Microstructure; Mechanical property; Corrosion; Cytotoxicity

Available online at http://link.springer.com/journal/40195

H. R. Bakhsheshi-Rad

rezabakhsheshi@pmt.iaun.ac.ir; rezabakhsheshi@gmail.com

1 Advanced Materials Research Center, Department of Materials Engineering, Najafabad Branch, Islamic Azad

University, Najafabad, Iran

2 Department of Materials, Manufacturing and Industrial Engineering, Faculty of Mechanical Engineering, Universiti Teknologi Malaysia, 81310 Johor Bahru, Johor, Malaysia

3 Research and Development Centre, KISWIRE Sdn. Bhd, Johor Bahru, Johor, Malaysia

4 Department of Materials and Mechanical Engineering, Buein Zahra Technical University, Qazvin 3451745346, Iran

5 Department of Mechanical and Materials Engineering, Masdar Institute of Science and Technology, P. O. Box: 54224, Masdar City, Abu Dhabi, UAE

6 Department of Mechanical Engineering, Concordia University, 1455 De Maisonneuve Blvd. West, Montreal, QC H3G 1M8, Canada

\section{Introduction}

$\mathrm{Zn}$ is one of the most abundant nutrition essential elements in the human body. It appears in all enzyme classes and has basic safety for biomedical applications [1]. The daily recommended intake of $\mathrm{Zn}$ is about $15 \mathrm{mg}$, and the excess is usually excreted through urine [2]. $\mathrm{Zn}$ concentration in normal blood serum level is $12.4-17.4 \mu \mathrm{mol} / \mathrm{L}$, which is essential for the immune system. It is also a cofactor for specific enzymes in bone and cartilage [3, 4]. For these reasons, zinc has a great potential to be used as biodegradable material. However, the extensive applications of zinc are hindered by its poor mechanical strength and hardness [5-7]. One of the main approaches for zinc as a biodegradable implant material is to improve its strength and elongation. Alloying $\mathrm{Zn}$ with other alloying elements, such as aluminum (Al) and magnesium $(\mathrm{Mg})$, is one of the main tools to obtain Zn-based alloys with enhanced mechanical properties [6, 8-10]. For instance, Vojtech et al. [8] showed that after addition of $1 \mathrm{wt} \% \mathrm{Mg}$ to $\mathrm{Zn}$ the maximum strength and elongation increase to $150 \mathrm{MPa}$ and 2\%, respectively. Kubásek et al. [9] revealed that $\mathrm{Zn}-$ 
$0.8 \mathrm{Mg}$ alloy presented the best combination of ultimate tensile strength and elongation. Mostaed et al. [10] investigated novel $\mathrm{Zn}-\mathrm{Mg}$ and $\mathrm{Zn}-\mathrm{Al}$ binary alloys as potential biodegradable materials for stent applications. Their result showed that $\mathrm{Zn}-0.5 \mathrm{Mg}$ is a suitable material for stent applications with a good combination of strength, ductility and strain hardening. In addition, their result exhibited that after addition of 0.5 and $1 \mathrm{wt} \% \mathrm{Al}$ to $\mathrm{Zn}$, the hardness, strength and ductility remarkably increased. The fact of using $\mathrm{Al}$ as an alloying element in biodegradable implants can be due to its degradation process, which involves releasing small and tolerable amounts of aluminum in a continuous manner within the body [11-14]. For some alloys, such as AZ31, aluminum does not diffuse into the surrounding tissue during the degradation of the alloy [15]. Addition of bismuth (Bi), which is a low-cost element with less toxicity than its neighboring elements in the periodic table, such as antimony, to Zn-based alloys leads to further improvement in the mechanical properties of the alloy [16]. Limited studies have been carried out on the biomedical applications of $\mathrm{Zn}-\mathrm{Al}-\mathrm{Mg}$ and $\mathrm{Zn}-\mathrm{Al}-\mathrm{Mg}-\mathrm{Bi}$ alloys. Therefore, in the present study the microstructure, corrosion behavior and cytotoxicity of the ternary and quaternary alloys have been investigated.

\section{Material and Methods}

Zn-based alloys were prepared by melting pure $\mathrm{Zn}$ chips (99.99 wt\%), pure $\mathrm{Mg}$ ingots $(99.98 \mathrm{wt} \%$ ), pure $\mathrm{Al}$ (99.99 wt\%) and pure Bi $(99.99 \mathrm{wt} \%)$ in an electrical resistance furnace under protective gas atmosphere. The elements were placed in a mild steel crucible coated with boron nitride. The crucible was held at a temperature of $580{ }^{\circ} \mathrm{C}$ for $20 \mathrm{~min}$ to melt the materials and further $10 \mathrm{~min}$ to allow for homogenization of the melt. The melt was partially poured directly into a $250{ }^{\circ} \mathrm{C}$ preheated mild steel mold. The remaining liquid was stirred for $30 \mathrm{~s}$ for thermal analysis. The chemical compositions of the $\mathrm{Zn}-\mathrm{Al}-\mathrm{Mg}-$ $x \mathrm{Bi}$ alloys were determined by inductively coupled plasma mass spectrometry (ICP) as listed in Table 1. For microstructural analysis, several specimens with dimensions of $10 \mathrm{~mm} \times 15 \mathrm{~mm} \times 15 \mathrm{~mm}$ were cut from the cast samples. The specimens were then ground and polished using SiC papers up to 4000 grits until a mirror-like surface was obtained. Subsequently, the polished samples were etched using $4 \%$ Nital solution to reveal the microstructural features. Thermal analysis was carried out with a thermocouple positioned in the center of the mild steel mold. Thermocouple was linked to an EPAD-TH8-K high-speed data acquisition system connected to a computer with DEWESoft 7.5 data analyzer. Recorded data were smoothed, plotted and analyzed using Flexpro8 data analysis software. X-ray diffractometer (Siemens-D500) was used for phase identification using $\mathrm{Cu}-K \alpha$ radiation generated at $40 \mathrm{kV}$ and $35 \mathrm{~mA}$. Microstructural observation was performed using a scanning electron microscope (SEM; JEOL JSM-6380LA). Thermal and microstructural analyses were supported by thermodynamic calculations of the vertical sections and phase assemblage diagrams for $\mathrm{Zn}-\mathrm{Mg}-\mathrm{Al}-\{\mathrm{Bi}\}$ alloys using FactSage software [17]. A three-electrode cell was used for potentiodynamic polarization tests (PDP) (PARSTAT 2263) and electrochemical impedance spectroscopy (EIS) in simulated body fluid (SBF) according to Ref. [18]. The immersion test procedure was carried out based on the ASTM standard G31-72. The Kokubo SBF was prepared according to the previously reported method [19] with a chemical composition given in Table 2. For potentiodynamic polarization, the samples were immersed in the SBF for $1 \mathrm{~h}$ prior to the test to establish the open-circuit potential for providing uniform corrosion and a well-defined Tafel region. PDP experiments ( $n=3$, where $n$ indicates the number of replicates) were carried out at a constant scan rate of $0.166 \mathrm{mV} / \mathrm{s}$ initiated at $-250 \mathrm{mV}_{\mathrm{SCE}}$ below the open-circuit potential. For immersion test, 20 rectangular specimens with a size of $10 \mathrm{~mm} \times 10 \mathrm{~mm}$ and $5 \mathrm{~mm}$ thickness were cut and subsequently ground and polished with 400- to 2000-grit SiC papers. The specimens were then washed entirely with distilled water, rinsed, ultrasonically degreased with ethanol and then dried at room temperature. The specimens were then immersed into a beaker containing $200 \mathrm{~mL}$ of Kokubo SBF. The $\mathrm{pH}$ value of the solution was adjusted to around 7.6 at $37{ }^{\circ} \mathrm{C}$ with $1.0 \mathrm{~mol} / \mathrm{L} \mathrm{HCl}$ and Tris. The beakers were sealed with a $\mathrm{pH}$ value of 7.66 and incubated at a constant temperature of $37^{\circ} \mathrm{C}$ for 7 days. Afterward,

Table 1 Chemical compositions of the $\mathrm{Zn}-0.5 \mathrm{Al}-0.5 \mathrm{Mg}-x \mathrm{Bi}$ alloys

\begin{tabular}{llllllll}
\hline Alloy & \multicolumn{3}{l}{ Analyzed compositions (wt\%) } & & \\
\cline { 2 - 7 } & Fe & $\mathrm{Al}$ & $\mathrm{Cu}$ & $\mathrm{Mg}$ & $\mathrm{Bi}$ & $\mathrm{Si}$ & $\mathrm{Zn}$ \\
\hline Zn-0.5Al-0.5Mg & 0.0 .08 & 0.47 & 0.004 & 0.56 & - & 0.022 & Bal. \\
Zn-0.5Al-0.5Mg-0.1Bi & 0.010 & 0.51 & 0.003 & 0.49 & 0.12 & 0.031 & Bal. \\
Zn-0.5Al-0.5Mg-0.3Bi & 0.011 & 0.49 & 0.005 & 0.52 & 0.32 & 0.026 & Bal. \\
Zn-0.5Al-0.5Mg-0.5Bi & 0.009 & 0.53 & 0.004 & 0.48 & 0.54 & 0.033 \\
\hline
\end{tabular}


Table 2 Chemical composition of the Kokubo simulated body fluid (SBF) compared to the human blood plasma

\begin{tabular}{lllllllll}
\hline Solution & \multicolumn{2}{l}{ Ion concentration (mmol/L) } & & & \\
\cline { 2 - 8 } & $\mathrm{Na}^{+}$ & $\mathrm{K}^{+}$ & $\mathrm{Ca}^{2+}$ & $\mathrm{Mg}^{2+}$ & $\mathrm{HCO}_{3}{ }^{-}$ & $\mathrm{Cl}^{-}$ & $\mathrm{HPO}_{4}{ }^{2-}$ & $\mathrm{SO}_{4}{ }^{2-}$ \\
\hline Plasma & 142.0 & 5.0 & 2.5 & 1.5 & 27.0 & 103.0 & 1.0 & 0.5 \\
Kokubo (c-SBF) & 142.0 & 5.0 & 2.5 & 1.5 & 4.2 & 147.8 & 1.0 & 0.5 \\
\hline
\end{tabular}

the specimens were rinsed with acetone and deionized water to remove the corrosion products before weight measurement. The corrosion rate was calculated as follows:

$C_{\mathrm{R}}=W /(A t d)$,

where $C_{\mathrm{R}}$ is the corrosion rate, $W$ is the mass loss, $A$ is the surface area exposed to the corrosive media, $t$ is the exposure time and $d$ is the density. The average $\mathrm{pH}(n=5)$ value of the SBF from three measurements was recorded during the experiment after 24-h time interval. Dog-bonetype tensile specimens were machined from the prepared alloys ingots with a $16 \mathrm{~mm}$ gage length, $4 \mathrm{~mm}$ diameter and $4 \mathrm{~mm}$ radius of fillet. Tensile tests were performed using an Instron-5569 universal testing machine at a displacement rate of $2.0 \mathrm{~mm} / \mathrm{min}$ and ambient temperature according to the ASTM-E8/E8 M-08 [20]. Tensile test was repeated three times to examine the reproducibility of the results. The average microhardness $(n=5)$ of the alloys was measured with a Vickers hardness tester (Shimadzu) using a 5-kg load. Methylthiazolyldiphenyl-tetrazolium bromide (MTT) method was used to evaluate the MC3T3E1 cell toxicity of the Zn-based alloys. Extracts were cultured for $24 \mathrm{~h}$ with the surface area/extraction medium ratio $1.25 \mathrm{~cm}^{2}: 1 \mathrm{~mL}$, and the concentrations were recorded. The extract was then withdrawn for the cytotoxicity test or, alternatively, refrigerated at $4{ }^{\circ} \mathrm{C}$ before the cytotoxicity test. The control groups involved the use of Dulbecco's modified Eagle's medium (DMEM) as negative control. Following the incubation of the cells in a humidified $5 \% \mathrm{CO}_{2}$ atmosphere at $37{ }^{\circ} \mathrm{C}$ for 2 and 7 days, the extracts were removed. The details of the MTT test can be found in Ref. [21].

\section{Results and Discussion}

\subsection{Microstructure Characterization}

An assembly of all cooling curves collected for $\mathrm{Zn}-0.5 \mathrm{Al}-$ $0.5 \mathrm{Mg}$ alloys without and with various $\mathrm{Bi}$ contents is shown in Fig. 1a. Three phase transformation temperatures were detected in the $\mathrm{Zn}-\mathrm{Al}-\mathrm{Mg}$ alloy. These temperatures were acquired at $407.9,352.5$ and $333.3{ }^{\circ} \mathrm{C}$. The cooling rate, calculated based on recorded cooling curve, was $0.5^{\circ} \mathrm{C} / \mathrm{s}$ prior to formation of the first peak (\#1). First derivative cooling curves (Fig. 1b, c) were plotted to determine the phase transformation temperatures precisely, as they are difficult to be identified directly from the cooling curve itself (Fig. 1a). It is worth mentioning that the derivative curves have been displaced along derivative axis for better presentation. Each phase transition appeared as a drastic change in derivative curve. Three phase transitions were observed in the ternary alloy as aforementioned and shown in Fig. 1a. However, a small peak close to the third peak was observed after addition of Bi. Figure $1 \mathrm{c}$ is a magnification of Fig. 1b, highlighting the difference between cooling behaviors of these alloys, which is of main interest in this study. In order to understand the variation in the cooling curve results, thermodynamic calculations of the $\mathrm{Zn}-\mathrm{Mg}-\mathrm{Al}$ and $\mathrm{Zn}-\mathrm{Mg}-\mathrm{Al}-\mathrm{Bi}$ alloying systems were done. The $\mathrm{Zn}-\mathrm{Mg}-\mathrm{Al}$ ternary phase diagram is very well described in the literature [22]. Other ternaries, $\mathrm{Al}-\mathrm{Bi}-\mathrm{Mg}$ and $\mathrm{Al}-\mathrm{Bi}-\mathrm{Zn}$, are included within the FactSage software database. Figure $2 \mathrm{a}, \mathrm{b}$ shows the calculated vertical sections for the ternary and quaternary alloys, respectively, at the composition of interest. The vertical section in the $\mathrm{Zn}-\mathrm{Al}-\mathrm{Mg}$ system, shown in Fig. 2a, was calculated at a constant $\mathrm{Zn}$ concentration of $99 \mathrm{wt} \%$. The ternary alloy with a composition of $\mathrm{Zn}-0.5 \mathrm{Al}-0.5 \mathrm{Mg}$ is presented as a dashed line, and phase transformation temperatures, obtained from the cooling curve experiment (Fig. 1a), are presented by the symbol $\nabla$ in the same figure. Accordingly, the alloy is expected to undergo four phase transformations at 407, 362, 360.8 and $243{ }^{\circ} \mathrm{C}$ upon cooling. As shown in Fig. 2a, the experimental and calculated liquidus temperatures agree very well with each other. The liquid $+\mathrm{HCP}-\mathrm{Zn}+\mathrm{Mg}_{2}(\mathrm{Zn}, \mathrm{Al})_{11}$ phase field starts and ends within a very narrow temperature range of 362 and $360.8{ }^{\circ} \mathrm{C}$, respectively. However, temperatures acquired for peaks (\#2) and (\#3), which correspond to the starting and ending points of liquid $+\mathrm{HCP}-\mathrm{Zn}+\mathrm{Mg}_{2}(\mathrm{Zn}, \mathrm{Al})_{11}$ phase field, differ slightly from the calculations. This variation is acceptable and could be due to the non-equilibrium cooling of the alloy. The solid-solid phase transformation temperature is difficult to be determined by cooling curve experiments. Thus, the temperature of HCP$\mathrm{Zn}+\mathrm{Mg}_{2}(\mathrm{Zn}, \quad \mathrm{Al})_{11}$ to $\mathrm{FCC}-\mathrm{Al}+\mathrm{HCP}-\mathrm{Zn}+\mathrm{Mg}_{2}(\mathrm{Zn}$, $\mathrm{Al})_{11}$ phase transformation was not possible to be detected experimentally. Figure $1 \mathrm{~b}$ shows a comparison between first derivative cooling curves of $\mathrm{Zn}-0.5 \mathrm{Al}-0.5 \mathrm{Mg}$ and $\mathrm{Zn}-$ 


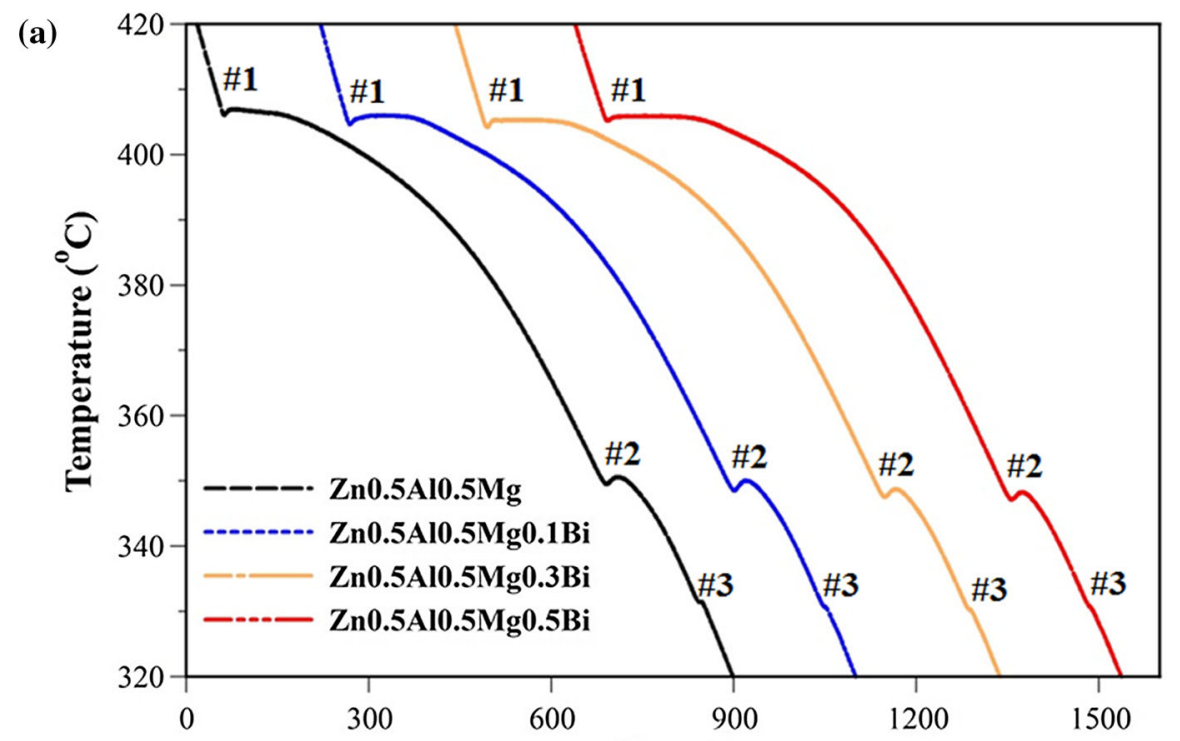

Time (s)

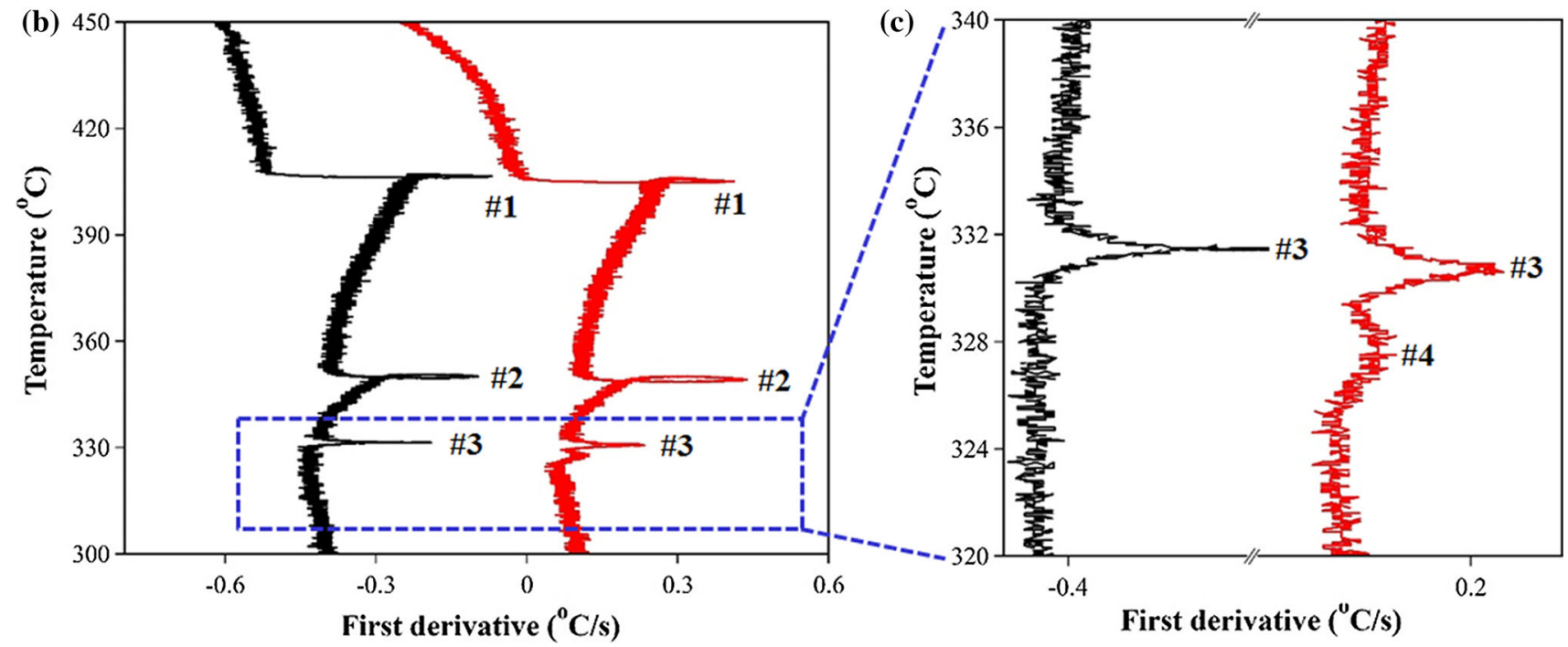

Fig. 1 a Assembly of cooling curves of all tested $\mathrm{Bi}$ addition levels to the $\mathrm{Zn}-0.5 \mathrm{Al}-0.5 \mathrm{Mg}$ alloy, b comparison of first derivative cooling curves of $\mathrm{Zn}-0.5 \mathrm{Al}-0.5 \mathrm{Mg}$ and $\mathrm{Zn}-0.5 \mathrm{Al}-0.5 \mathrm{Mg}-0.1 \mathrm{Bi}$, $\mathbf{c}$ the magnified of Fig. $1 \mathrm{~b}$ showing clearly a new peak after addition of $0.1 \mathrm{wt} \% \mathrm{Bi}$

$0.5 \mathrm{Al}-0.5 \mathrm{Mg}-0.1 \mathrm{Bi}$ alloys. It is apparent that with addition of $\mathrm{Bi}$, a new peak (\#4) was detected at $328^{\circ} \mathrm{C}$. The vertical section at $0.5 \mathrm{Al}-0.5 \mathrm{Mg}$ and $0-0.7 \mathrm{wt} \% \mathrm{Bi}$, balanced with $\mathrm{Zn}$, calculated in Fig. $2 \mathrm{~b}$, is an attempt to adjust the thermal analysis results of the quaternary alloy. According to this figure, peak (\#4) does not correspond to any occurring phase transformation in equilibrium conditions. With reference to the equilibrium diagram (Fig. 2b), the FCC-Al phase forms from solid below $250{ }^{\circ} \mathrm{C}$, whereas under the non-equilibrium cooling conditions, FCC-Al is found to form from liquid at $351^{\circ} \mathrm{C}$ and continues to precipitate further from solid. Thus, peak (\#4) might correspond to the liquid phase termination point in the non-equilibrium cooling condition.
Figure 3a-d shows the SEM micrographs of $\mathrm{Zn}-0.5 \mathrm{Al}-$ $0.5 \mathrm{Mg}$ and $\mathrm{Zn}-0.5 \mathrm{Al}-0.5 \mathrm{Mg}-\mathrm{Bi}$ alloys with different $\mathrm{Bi}$ contents. Figure $3 \mathrm{a}$ shows the microstructure of the $\mathrm{Zn}-$ $0.5 \mathrm{Al}-0.5 \mathrm{Mg}$ ternary alloy. The eutectic phase with a lamellar structure was formed within the grain boundaries. The EDS area analysis further confirmed that the eutectic phase contains $\mathrm{HCP}-\mathrm{Zn}+\mathrm{Mg}_{2}(\mathrm{Zn}, \mathrm{Al})_{11}$ as shown in Fig. 3e and f. $\mathrm{Mg}_{2}(\mathrm{Zn}, \mathrm{Al})_{11}$ ternary solid solution exhibits a mutual solid solubility between $\mathrm{Zn}$ and $\mathrm{Al}$ with a ratio of $6: 5$, respectively. Thus, the chemical formula of this phase can be expressed as $\mathrm{Mg}_{7.6} \mathrm{Zn}_{23} \mathrm{Al}_{19.2}$, which matches exactly with the measured composition of the three elements in at.\%. Remaining $\mathrm{Zn}$ concentration corresponds to the HCP-Zn phase. The addition of $0.1,0.3$ and $0.5 \mathrm{wt} \% \mathrm{Bi}$ 

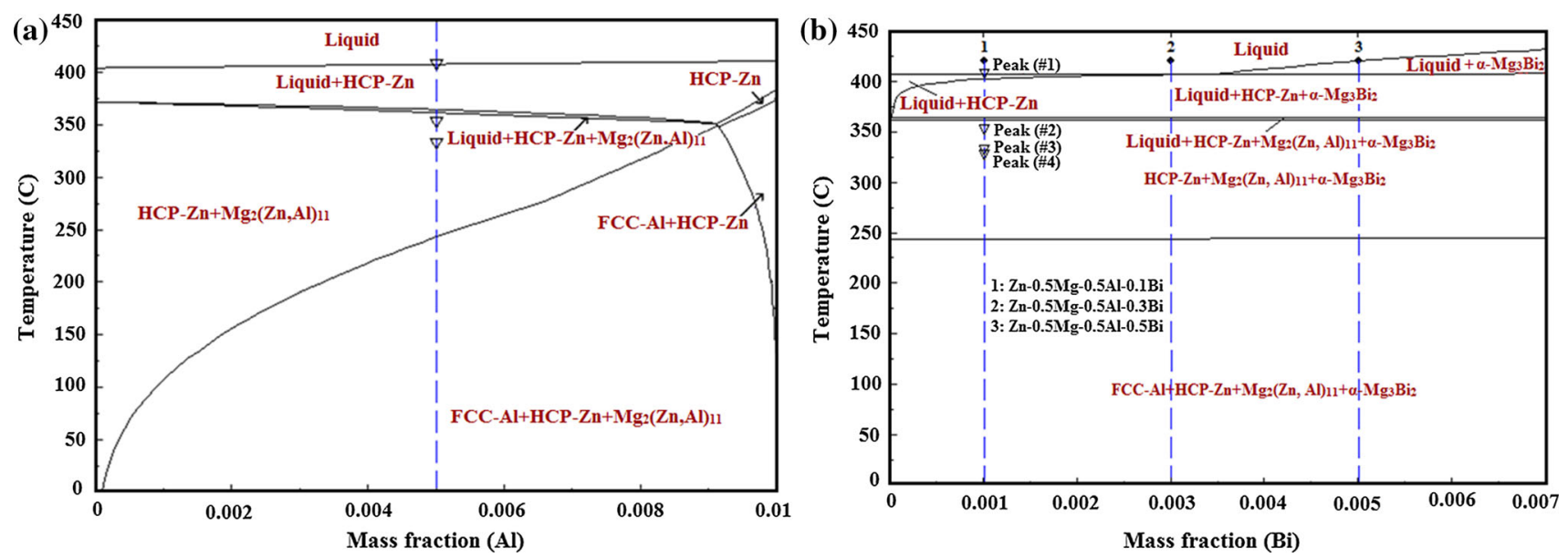

Fig. 2 Calculated vertical section of a $\mathrm{Zn}-\mathrm{Al}-\mathrm{Mg}$ alloy at a constant $\mathrm{Zn}$ concentration of 99 wt\%; b $\mathrm{Zn}-\mathrm{Al}-\mathrm{Mg}-\mathrm{Bi}$ alloys at $0.1,0.3$ and $0.5 \mathrm{wt} \% \mathrm{Bi}$. Dashed lines represent the target compositions of $\mathrm{Zn}-0.5 \mathrm{Al}-0.5 \mathrm{Mg}$ in a and $\mathrm{Zn}-0.5 \mathrm{Al}-0.5 \mathrm{Mg}-x \mathrm{Bi}(x=0.1,0.3$ and $0.5 \mathrm{wt} \%)$ in b. Inverted triangle experimental points obtained from cooling curve analysis

to $\mathrm{Zn}-0.5 \mathrm{Al}-0.5 \mathrm{Mg}$ further confirms the precipitation of a new phase within the grains, in addition to HCP$\mathrm{Zn}+\mathrm{Mg}_{2}(\mathrm{Zn}, \mathrm{Al})_{11}$ eutectic, as shown in Fig. 3b-d. The corresponding EDS spectrum shows the new phase as $\alpha$ $\mathrm{Mg}_{3} \mathrm{Bi}_{2}$. The XRD result of ternary $\mathrm{Zn}-\mathrm{Al}-\mathrm{Mg}$ alloy shows the peaks of FCC-Al, HCP- $\mathrm{Zn}$ and $\mathrm{Mg}_{2}(\mathrm{Zn}, \mathrm{Al})_{11}$ phases (Fig. 3h). The $\alpha-\mathrm{Mg}_{3} \mathrm{Bi}_{2}$ spectrum peaks were not positively recognized by XRD analysis. This can be attributed to the small amount of $\alpha-\mathrm{Mg}_{3} \mathrm{Bi}_{2}$, which is lower than the detection limit of the XRD.

Microstructural analysis was supported by calculating the phase assemblage diagrams, shown in Fig. 4, which is used to predict the room-temperature microstructure. Figure $4 \mathrm{a}$ shows the phase assemblage diagram of $\mathrm{Zn}-0.5 \mathrm{Al}-$ $0.5 \mathrm{Mg}$ alloy. The room-temperature microstructure of this ternary alloy consists of FCC-Al $+\mathrm{HCP}-\mathrm{Zn}+\mathrm{Mg}_{2}(\mathrm{Zn}$, $\mathrm{Al})_{11}$, and their relative amounts are $0.5,91.7$ and $7.8 \%$, respectively. Based on this calculation, HCP-Zn starts to precipitate from liquid at $406{ }^{\circ} \mathrm{C}$. The remaining liquid solidifies further to form a binary eutectic consisting of HCP-Zn $+\mathrm{Mg}_{2}(\mathrm{Zn}, \mathrm{Al})_{11}$ at $362^{\circ} \mathrm{C}$. Then, FCC-Al precipitates from the solid at $243{ }^{\circ} \mathrm{C}$ upon further cooling. These results agree very well with the observed microstructure and the EDS area analysis shown in Fig. 3a and e, respectively. It is worth mentioning that FCC-Al phase was not observed in the SEM micrograph in Fig. 3a. It can be due to the very low percentage of Al, calculated as $0.5 \mathrm{wt} \%$, which could be below the detection limit of the EDS. When $\mathrm{Bi}$ is added to the ternary alloy, the lowtemperature phase $\alpha-\mathrm{Mg}_{3} \mathrm{Bi}_{2}$ forms and appears in the microstructure at room temperature. The same was concluded from SEM micrographs and EDS analysis in Fig. 3b-d, $f$ and g. The relative amount of $\alpha-\mathrm{Mg}_{3} \mathrm{Bi}_{2}$ increases with the Bi concentration in the quaternary alloy. This can be clearly inferred from the phase assemblage diagrams shown in Fig. 4b-d. The relative amounts of the solid phases in the alloys studied in this work at room temperature are listed in Table 3.

\subsection{Mechanical Properties}

The mechanical properties of the ternary $\mathrm{Zn}-\mathrm{Al}-\mathrm{Mg}$ alloys in comparison with quaternary $\mathrm{Zn}-\mathrm{Al}-\mathrm{Mg}-\mathrm{Bi}$ alloys are shown in Fig. 5. The mechanical properties measurements showed that the $92 \pm 2 \mathrm{MPa}$ tensile strength (TS) and $1.73 \% \pm 0.16 \%$ elongation of the ternary alloy increased to $108 \pm 4 \mathrm{MPa}$ and $2.74 \% \pm 0.31 \%$, respectively, after the addition of $0.3 \mathrm{wt} \% \mathrm{Bi}$. However, the TS and elongation decreased to $98 \pm 3 \mathrm{MPa}$ and $1.97 \% \pm 0.21 \%$, respectively, for the $0.5 \mathrm{wt} \% \mathrm{Bi}$-containing alloy. This can be due to the presence of $\alpha-\mathrm{Mg}_{3} \mathrm{Bi}_{2}$ with needle shape, which acts as stress concentration and consequently crack initiation regions [23]. The hardness value of the $\mathrm{Zn}-\mathrm{Al}-$ $\mathrm{Mg}$ alloy was $94 \pm 4 \mathrm{HV}$, and this value increased to $102 \pm 5$ and $109 \pm 5 \mathrm{HV}$ with increase of 0.1 and 0.3 in Bi content, respectively. This can be attributed to precipitation of the secondary phase within the $\mathrm{Zn}$ matrix, which acts as an obstacle for grain boundary sliding and thus restricting further grain growth [9]. However, further addition of $\mathrm{Bi}$ to $0.5 \mathrm{wt} \%$ decreased the hardness value to $99 \pm 4 \mathrm{HV}$, which might be due to the formation of more secondary phase with needle shape at the grain boundary regions.

\subsection{Corrosion Behavior}

Figure 6a shows polarization curves of $\mathrm{Zn}-\mathrm{Al}-\mathrm{Mg}$ alloy in comparison with $\mathrm{Zn}-\mathrm{Al}-\mathrm{Mg}-\mathrm{Bi}$ alloys in Kokubo solution. The results of the electrochemical test showed that the $\mathrm{Zn}-$ $\mathrm{Al}-\mathrm{Mg}$ has more negative potential $\left(-1028 \pm 10 \mathrm{mV}_{\mathrm{SCE}}\right)$ 

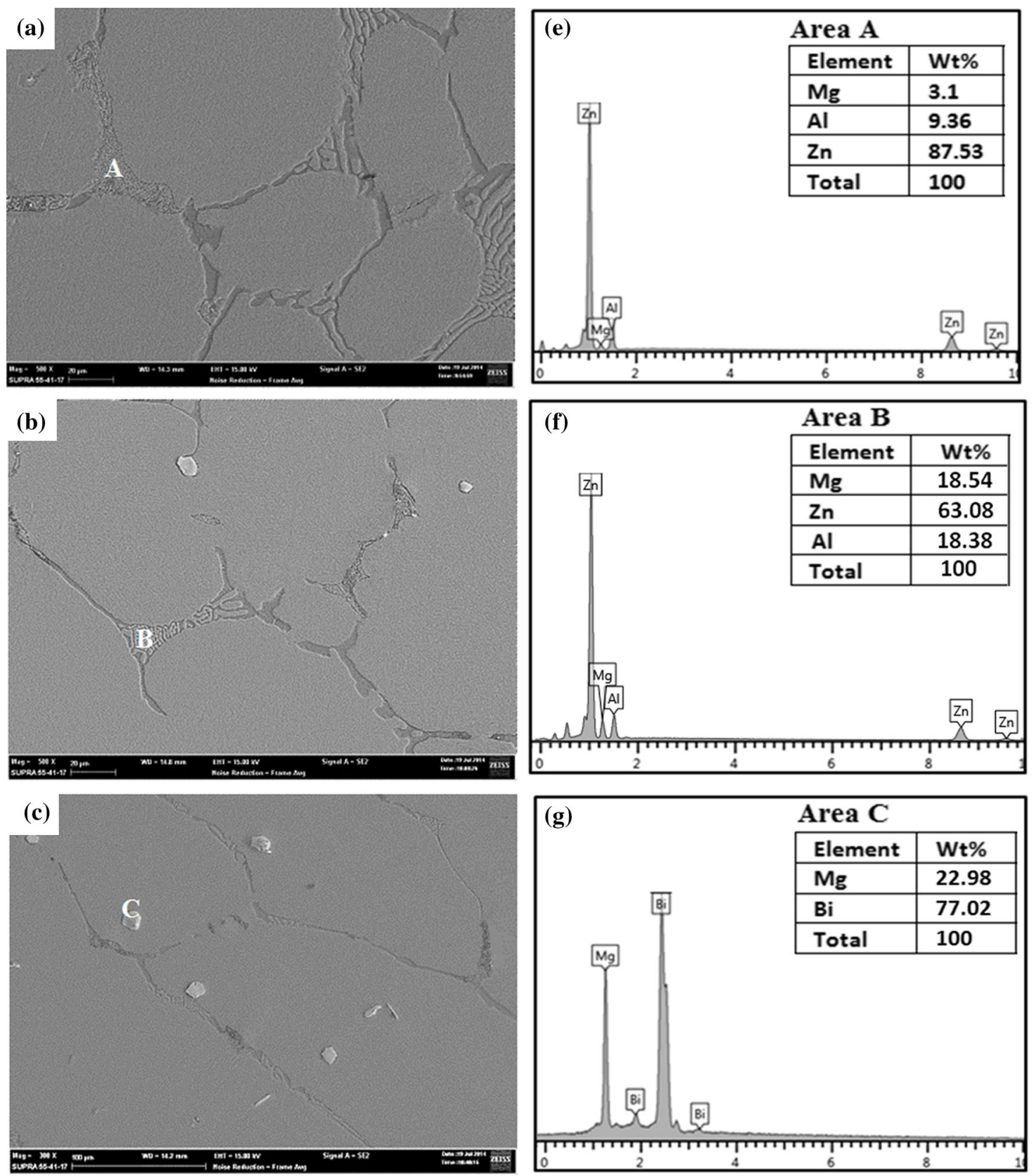

(d)
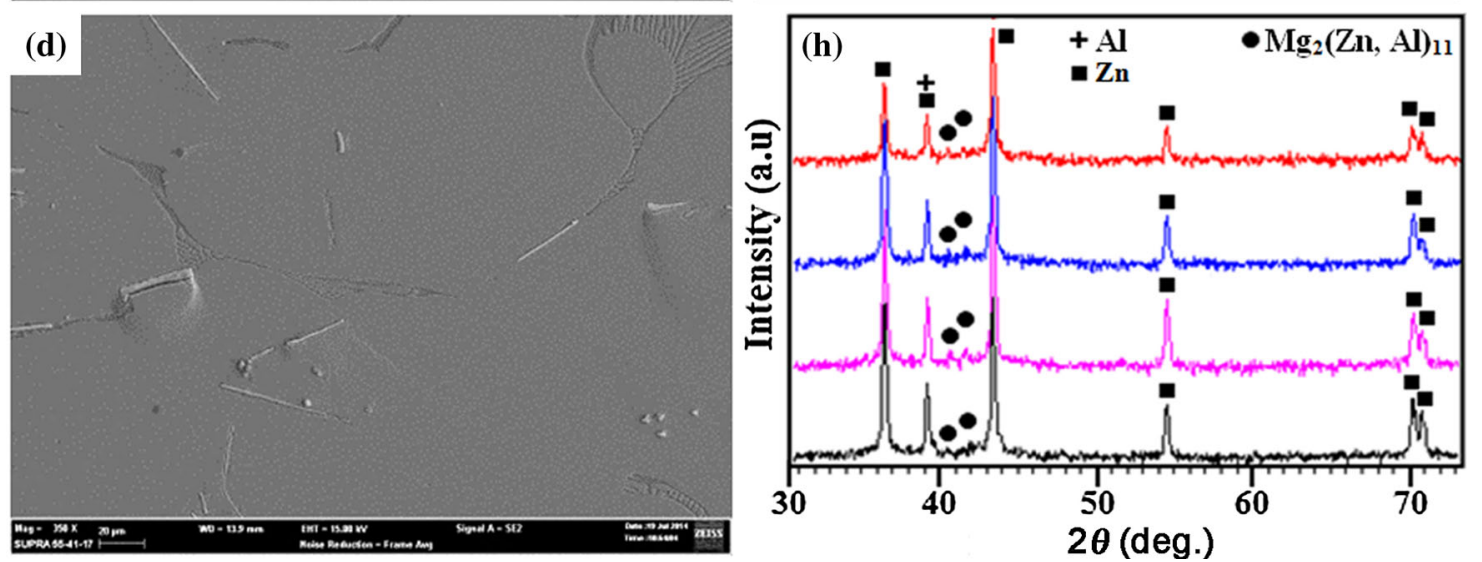
4Fig. 3 SEM micrographs of a $\mathrm{Zn}-0.5 \mathrm{Al}-0.5 \mathrm{Mg}$ alloy with various $\mathrm{Bi}$ contents: b $0.1, \mathbf{c ~} 0.3, \mathbf{d} 0.5 \mathrm{wt} \%$ and EDS analysis of e area A; $\mathbf{f}$ area $\mathrm{B}$ and $\mathbf{g}$ area $\mathrm{C}, \mathbf{h}$ X-ray diffraction patterns of $\mathrm{Zn}-0.5 \mathrm{Al}-0.5 \mathrm{Mg}-x \mathrm{Bi}$ alloys

than $\mathrm{Zn}-\mathrm{Al}-\mathrm{Mg}-0.1 \mathrm{Bi}\left(-1049 \pm 11 \mathrm{mV}_{\mathrm{SCE}}\right), \mathrm{Zn}-\mathrm{Al}-\mathrm{Mg}-$ $0.3 \mathrm{Bi}\left(-1065 \pm 11 \mathrm{mV}_{\mathrm{SCE}}\right)$ and $\mathrm{Zn}-\mathrm{Al}-\mathrm{Mg}-0.5 \mathrm{Bi}$ alloys $\left(-1084 \pm 12 \mathrm{mV}_{\mathrm{SCE}}\right)$, indicating that $\mathrm{Bi}$ has negative effect on the corrosion resistant of the alloys. The corrosion current density of the $\mathrm{Zn}-\mathrm{Al}-\mathrm{Mg}$ alloy was $9.51 \pm 0.08 \mu \mathrm{A} / \mathrm{cm}^{2}$, which is lower than that of the $\mathrm{Zn}-\mathrm{Al}-\mathrm{Mg}-0.1 \mathrm{Bi}$ alloy $\left(12.11 \pm 1.03 \mu \mathrm{A} / \mathrm{cm}^{2}\right)$. This can be attributed to the formation of galvanic micro-cells between $\mathrm{Zn}$ and $\mathrm{Mg}_{2}(\mathrm{Zn}$,
$\mathrm{Al})_{11}$, which increases corrosion rate of the base alloy [23]. Also, corrosion current density $\left(i_{\text {corr }}\right)$ increased to $16.45 \pm 1.13$ and $22.73 \pm 1.42 \mu \mathrm{A} / \mathrm{cm}^{2}$ after the addition of 0.3 and $0.5 \mathrm{wt} \% \mathrm{Bi}$ to the $\mathrm{Zn}-\mathrm{Al}-\mathrm{Mg}$ alloy, respectively. The main reason of higher $i_{\text {corr }}$ of $\mathrm{Zn}-\mathrm{Al}-\mathrm{Mg}-0.5 \mathrm{Bi}$ compared to $\mathrm{Zn}-\mathrm{Al}-\mathrm{Mg}-0.1 \mathrm{Bi}$ is the formation of more secondary phase $\left(\alpha-\mathrm{Mg}_{3} \mathrm{Bi}_{2}\right)$, as concluded from the thermodynamic calculations, which causes more galvanic corrosion between $\mathrm{Zn}$ and the precipitated secondary phases and consequently reduces the corrosion resistance of the quaternary alloys.
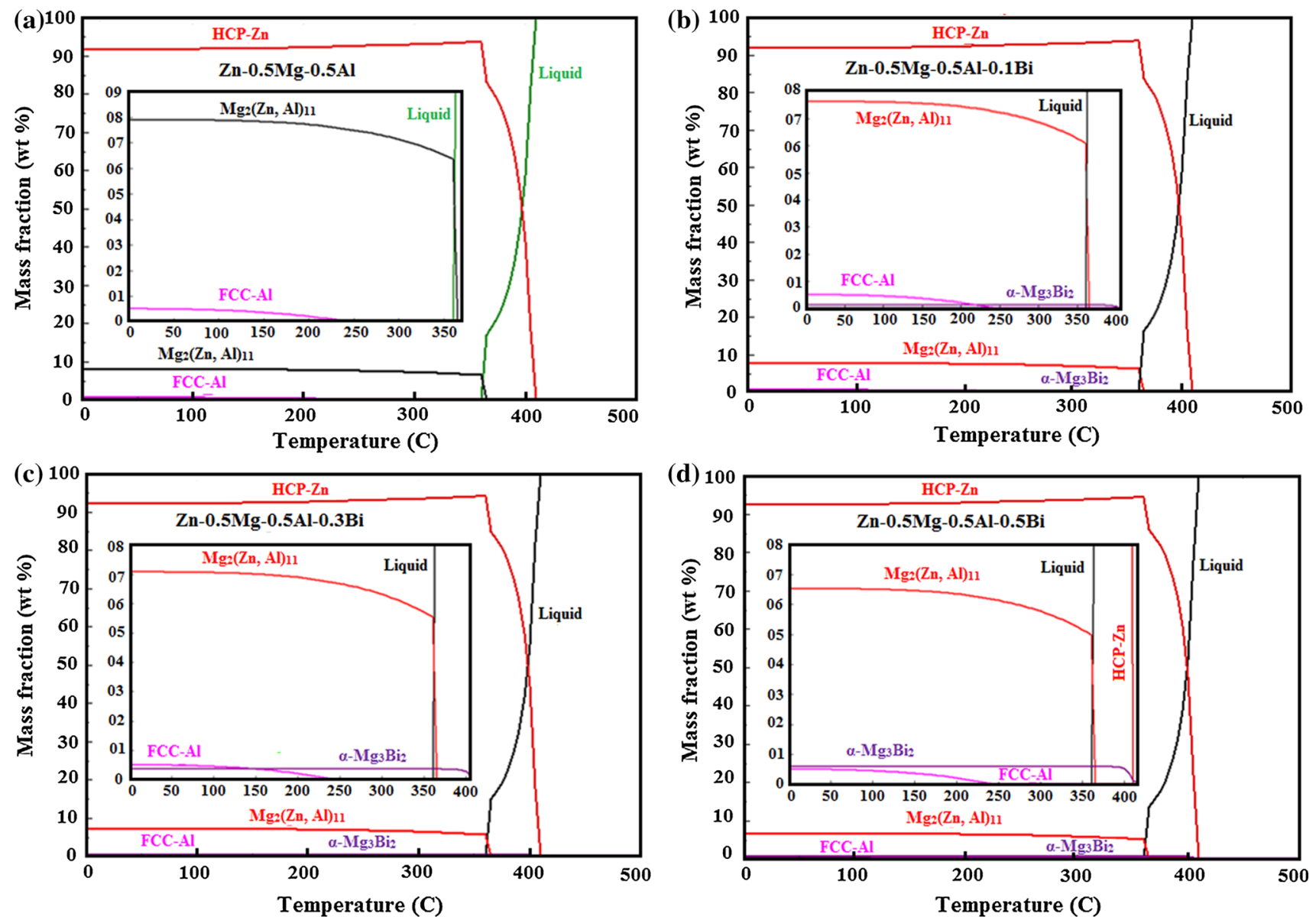

Fig. 4 Phase assemblage diagram of a $\mathrm{Zn}-0.5 \mathrm{Al}-0.5 \mathrm{Mg}$ alloy, $\mathbf{b}-\mathbf{d} \mathrm{Zn}-0.5 \mathrm{Al}-0.5 \mathrm{Mg}-x \mathrm{Bi}(x=0.1,0.3$ and $0.5 \mathrm{wt} \%)$

Table 3 Relative amounts of the solid phases in the studied alloys at room temperature

\begin{tabular}{lllll}
\hline Alloy & \multicolumn{2}{l}{ Phases and amounts at room temperature } & \\
\cline { 2 - 5 } & HCP-Zn & $\mathrm{Mg}_{2}(\mathrm{Zn}, \mathrm{Al})_{11}$ & $\mathrm{FCC}-\mathrm{Al}$ & $\alpha-\mathrm{Mg}_{3} \mathrm{Bi}{ }_{2}$ \\
\hline $\mathrm{Zn}-0.5 \mathrm{Mg}-0.5 \mathrm{Al}$ & $91.61 \pm 1.42$ & $7.85 \pm 0.92$ & $0.49 \pm 0.05$ & - \\
$\mathrm{Zn}-0.5 \mathrm{Mg}-0.5 \mathrm{Al}-0.1 \mathrm{Bi}$ & $91.77 \pm 1.78$ & $7.61 \pm 0.84$ & $0.49 \pm 0.05$ & $0.11 \pm 0.01$ \\
$\mathrm{Zn}-0.5 \mathrm{Mg}-0.5 \mathrm{Al}-0.3 \mathrm{Bi}$ & $92.08 \pm 1.51$ & $7.06 \pm 0.78$ & $0.49 \pm 0.05$ & $0.35 \pm 0.04$ \\
$\mathrm{Zn}-0.5 \mathrm{Mg}-0.5 \mathrm{Al}-0.5 \mathrm{Bi}$ & $92.40 \pm 1.25$ & $6.51 \pm 0.73$ & $0.49 \pm 0.05$ & $0.58 \pm 0.06$ \\
\hline
\end{tabular}




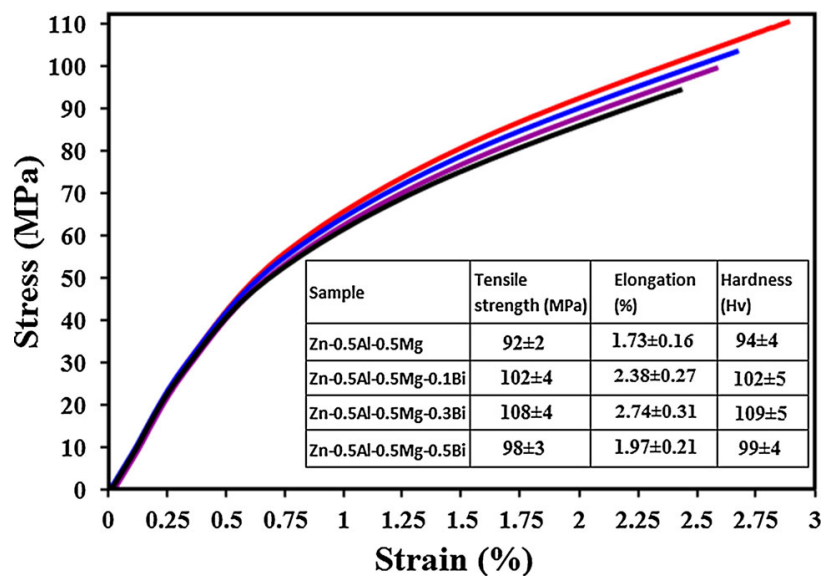

Fig. 5 Typical stress-strain curve of $\mathrm{Zn}-0.5 \mathrm{Al}-0.5 \mathrm{Mg}$ and $\mathrm{Zn}-$ $0.5 \mathrm{Al}-0.5 \mathrm{Mg}-x \mathrm{Bi}(x=0.1,0.3$ and $0.5 \mathrm{wt} \%)$

The Nyquist plot of ternary and quaternary Zn-based alloys was composed of two capacitive loops in the highfrequency range and medium-frequency ranges (Fig. 6b). The high-frequency (HF) part of the diagram essentially represents the film resistance, and the medium-frequency (MF) capacitive loop is related to the relaxation of the mass transport in the solid phase that is a result of the formation of a layer of the corrosion products [24]. The EIS spectra of ternary and quaternary alloys have similar patterns but different diameters. This shows that the alloys have similar corrosion mechanisms but different rates. The graph shows that the addition of $\mathrm{Bi}$ to $\mathrm{Zn}-\mathrm{Al}-\mathrm{Mg}$ alloy leads to a decrease in the diameter of the capacitive loop, which means a decrease in corrosion resistance. The presence of $\alpha-\mathrm{Mg}_{3} \mathrm{Bi}_{2}$ phase in the Bi-containing alloys results in more galvanic potential between $\mathrm{Zn}$ matrix and $\alpha-\mathrm{Mg}_{3} \mathrm{Bi}_{2}$, which decreases the corrosion resistance.

Figure 7 shows the surface morphologies of $\mathrm{Zn}-\mathrm{Al}-\mathrm{Mg}$ and $\mathrm{Zn}-\mathrm{Al}-\mathrm{Mg}-x \mathrm{Bi}$ alloys after $720-\mathrm{h}$ immersion in the
Kokubo solution. Figure $7 \mathrm{a}$ and e shows that the surface of the ternary $\mathrm{Zn}-\mathrm{Al}-\mathrm{Mg}$ alloys is uniformly covered by insoluble and relatively compact corrosion products with spherical morphologies, which can act as a protective barrier film from aggressive corrosion attack [18]. However, the surface of $\mathrm{Zn}-\mathrm{Al}-\mathrm{Mg}-x \mathrm{Bi}$ alloys is partially covered by loosely packed white product with irregular morphologies (Fig. 7b-h). The EDS analysis of the corrosion layer reveals that the surface structure consists of $\mathrm{Mg}, \mathrm{P}, \mathrm{Ca}$ and $\mathrm{O}$. This composition indicates the formation of calcium-magnesium phosphates as shown in Fig. 7i-l. From this point of view, the TEM images display that the calcium-magnesium phosphates particles formed in the alloy surface are spherical in shape with an average particle size of $40-85 \mathrm{~nm}$ (Fig. 8a, b). The entire of the spherical structures combine with each other and hence the boundaries become blurred. Calcium-magnesium phosphate particles have a chemical composition similar to the natural bone, which improves bioactivity and osteoconductivity. The selected area electron diffraction (SAED) pattern of spherical shaped particle further confirmed the formation of calcium-phosphate phases and the pattern shows the poly-crystallinity of the particles (Fig. 8c).

Figure 9a shows that the $\mathrm{pH}$ values of SBF solutions for Zn-based alloys tended to increase at the early immersion stage due to the formation of significant amount of the $\mathrm{OH}^{-}$ion. The $\mathrm{pH}$ number of the solution remained at a semi-stable value at the longer time due to the formation of calcium-magnesium phosphates that consumes the $\mathrm{OH}^{-}$in the SBF solution, which may indicate enhancing the bioactivity of the samples [6]. From the graph, it can also be inferred that $\mathrm{Zn}-\mathrm{Al}-\mathrm{Mg}$ alloy shows a lower slope compared to all other $\mathrm{Zn}-\mathrm{Al}-\mathrm{Mg}-x \mathrm{Bi}$ alloys, indicating its excellent corrosion resistant due to the generation of lower $\mathrm{Zn}^{+2}$ ions. (a)

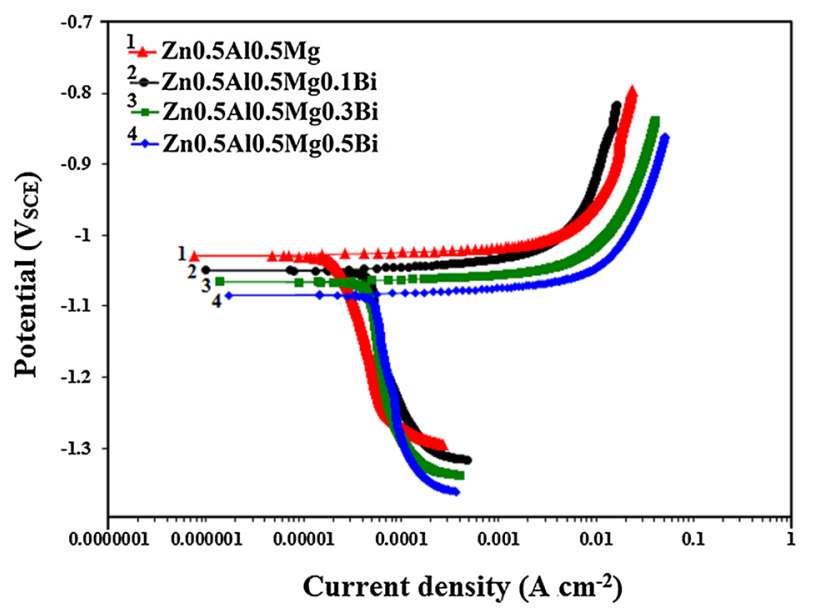

(b)

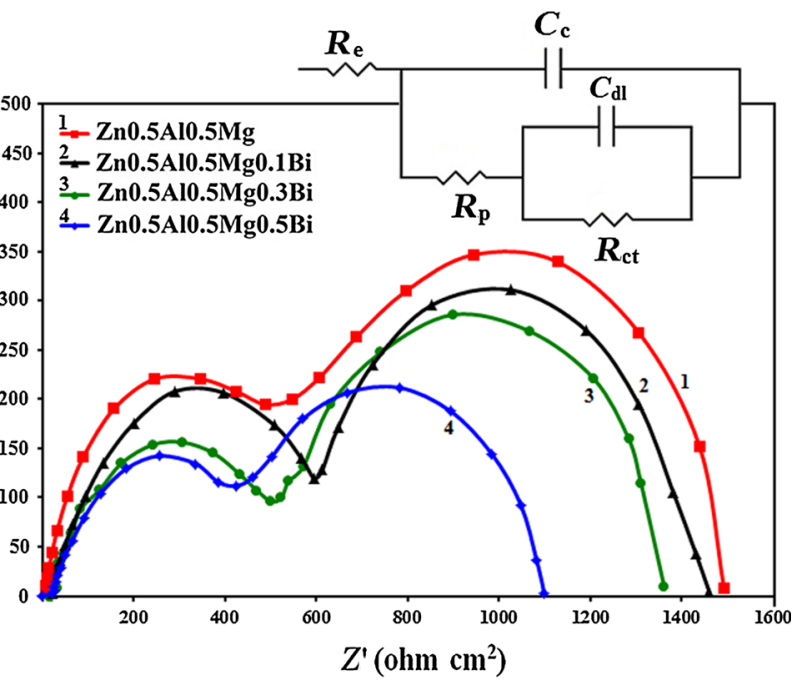

Fig. 6 a Potentiodynamic polarization curves and $\mathbf{b}$ electrochemical impedance spectroscopy measurements of $\mathrm{Zn}-0.5 \mathrm{Al}-0.5 \mathrm{Mg}-x \mathrm{Bi}$ alloys 

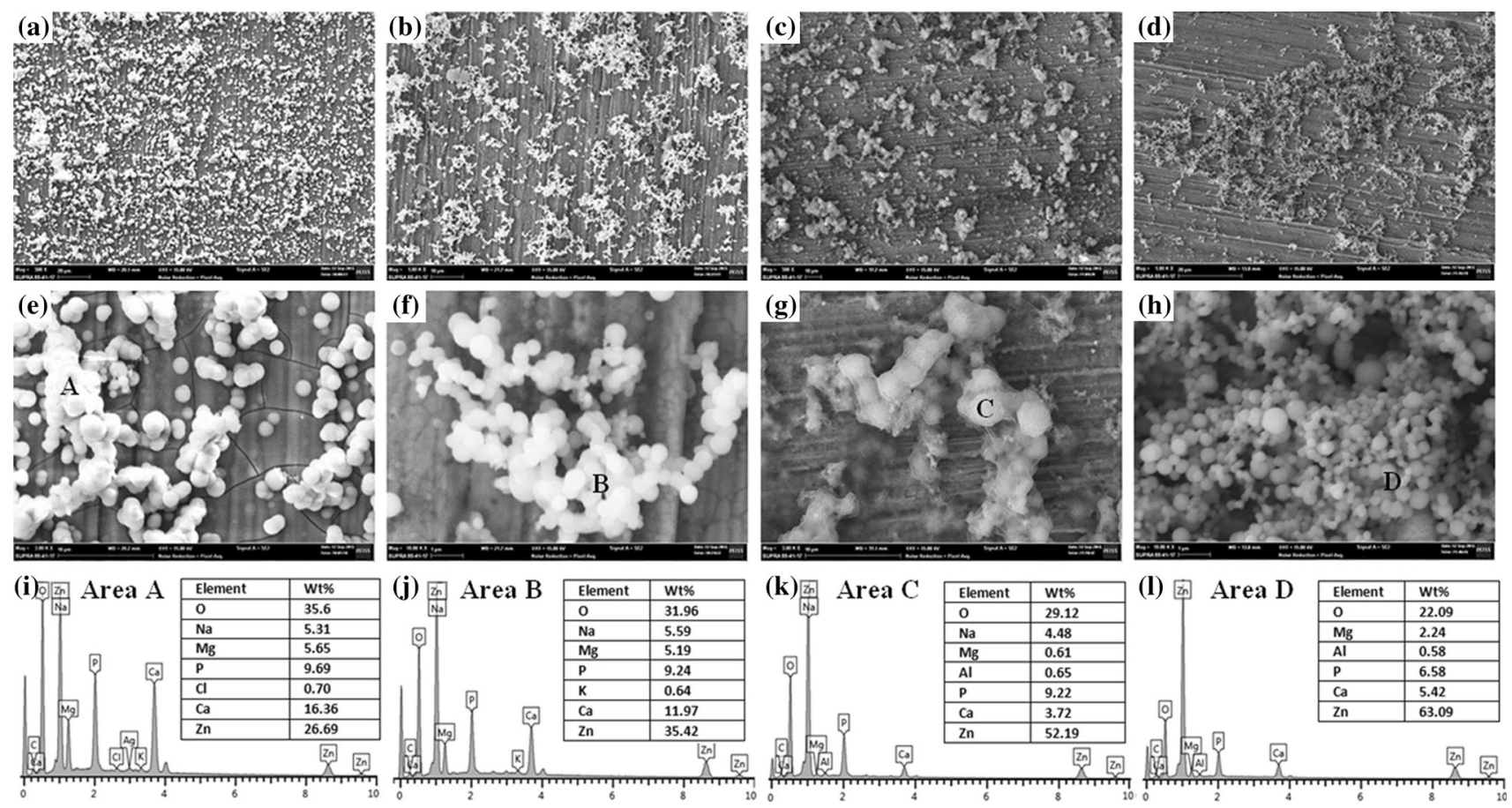

Fig. 7 SEM morphology of a, e Zn-0.5Al-0.5Mg alloy with various Bi contents: $\mathbf{b}, \mathbf{f} 0.1, \mathbf{c}, \mathbf{g} 0.3, \mathbf{d}, \mathbf{h} 0.5$ wt $\%$ after 720 h of immersion in SBF and EDS analysis of $\mathbf{i}$ area $\mathrm{A}, \mathbf{j}$ area $\mathrm{B}, \mathbf{k}$ area $\mathrm{C}, \mathbf{l}$ area D
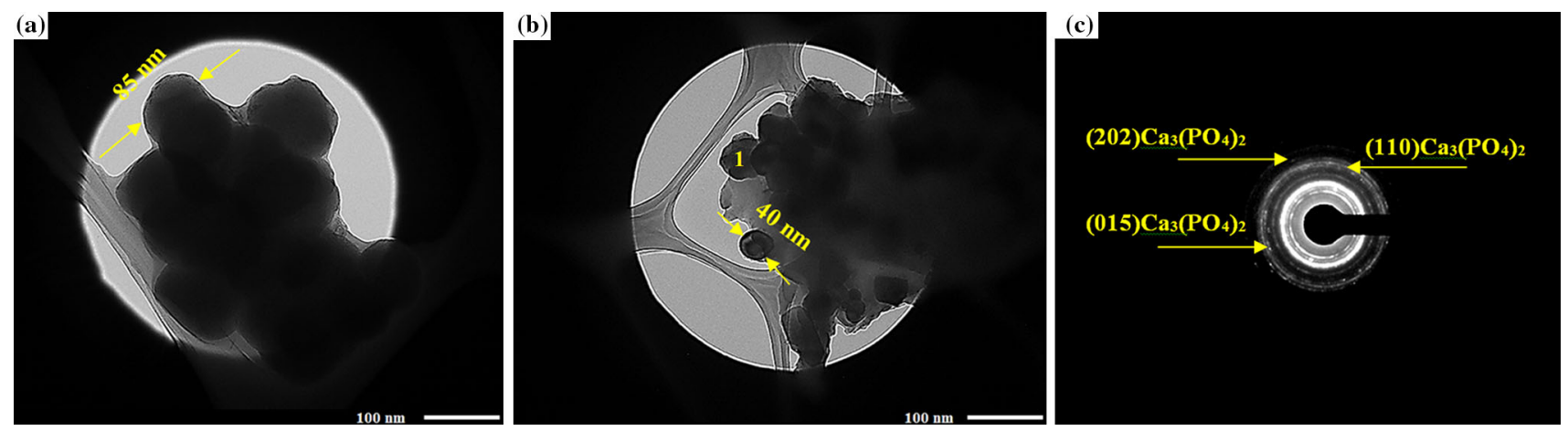

Fig. 8 TEM micrographs of corrosion products of a $\mathrm{Zn}-0.5 \mathrm{Al}-0.5 \mathrm{Mg}$ alloy and $\mathbf{b} \mathrm{Zn}-0.5 \mathrm{Al}-0.5 \mathrm{Mg}-0.5 \mathrm{Bi}$ alloy, $\mathbf{c}$ selected area electron diffraction (SAED) of area 1

The weight loss of the $\mathrm{Zn}-\mathrm{Al}-\mathrm{Mg}$ sample is slightly lower than that of $\mathrm{Zn}-\mathrm{Al}-\mathrm{Mg}-x \mathrm{Bi}$ samples (Fig. 9b). The weight loss of the $\mathrm{Zn}-\mathrm{Al}-\mathrm{Mg}$ sample is $0.148 \pm 0.012 \mathrm{~mm} / \mathrm{year}$, which demonstrates a low degradation rate. The weight loss of Zn-based alloy increased to $0.174 \pm 0.018 \mathrm{~mm} /$ year after $0.1 \mathrm{wt} \% \mathrm{Bi}$, while further addition of $\mathrm{Bi}$ to $0.5 \mathrm{wt} \%$ leads to further increase in the weight loss $(0.283 \pm 0.024 \mathrm{~mm} /$ year). This is an indication that the degradation rate of the alloy increases with increasing the amount of $\mathrm{Bi}$.

\subsection{Cytotoxicity Evaluation}

Figure 10 shows the cell viability cultured in Zn-based ternary and quaternary alloys extraction medium. It was reported [25] that cells culture is an essential in vitro method in the cytocompatibility assessment of a new biomaterial. The cytotoxicity testing serves as a key indicator for quickly screening the biocompatibility of an alloy, and it is vital to measure the toxicity effect of elements for biomedical applications [26]. The extracts of the $\mathrm{Zn}-\mathrm{Al}-\mathrm{Mg}$ alloy resulted in the increase in the viability of MC3T3-E1 cells compared to the control group. Meanwhile, addition of $\mathrm{Bi}$ from 0.1 to $0.5 \mathrm{wt} \%$ to the ternary alloy reduced the viability of MC3T3-E1 as compared to that of $\mathrm{Zn}-\mathrm{Al}-\mathrm{Mg}$ alloy and negative control group due to the higher dissolution rate and high $\mathrm{pH}$ value of the alloy containing $\mathrm{Bi}$ when they are exposed to physiological environments [27]. In this view, Zhou et al. [28] investigated the in vitro cytocompatibility of binary $\mathrm{Zr}-1 X(X=\mathrm{Ti}, \mathrm{Nb}, \mathrm{Mo}, \mathrm{Cu}, \mathrm{Au}, \mathrm{Pd}, \mathrm{Ag}, \mathrm{Ru}, \mathrm{Hf}$ 

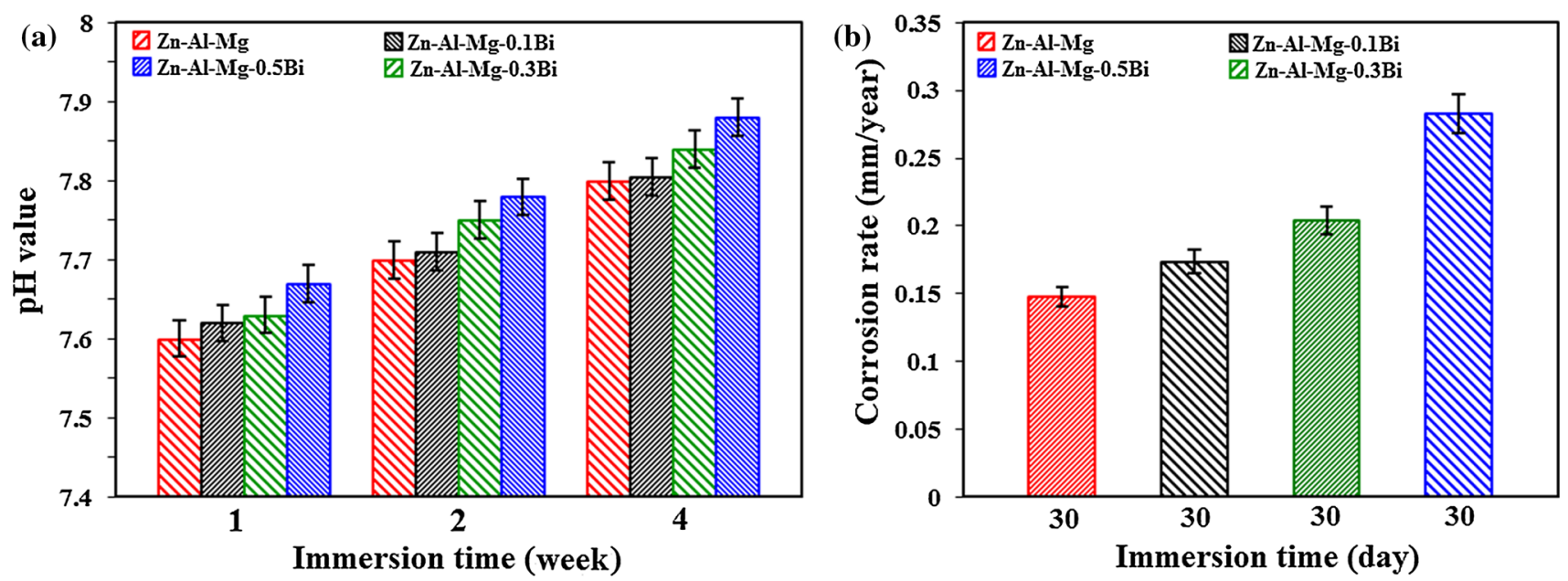

Fig. 9 a Change in $\mathrm{pH}$ value and $\mathbf{b}$ corrosion rate of $\mathrm{Zn}-0.5 \mathrm{Al}-0.5 \mathrm{Mg}$ and $\mathrm{Zn}-0.5 \mathrm{Al}-0.5 \mathrm{Mg}-x \mathrm{Bi}(x=0.1,0.3$ and 0.5 wt $\%)$ in $\mathrm{Kokubo}$ solution. Error bars show standard deviation for $n=3$ samples

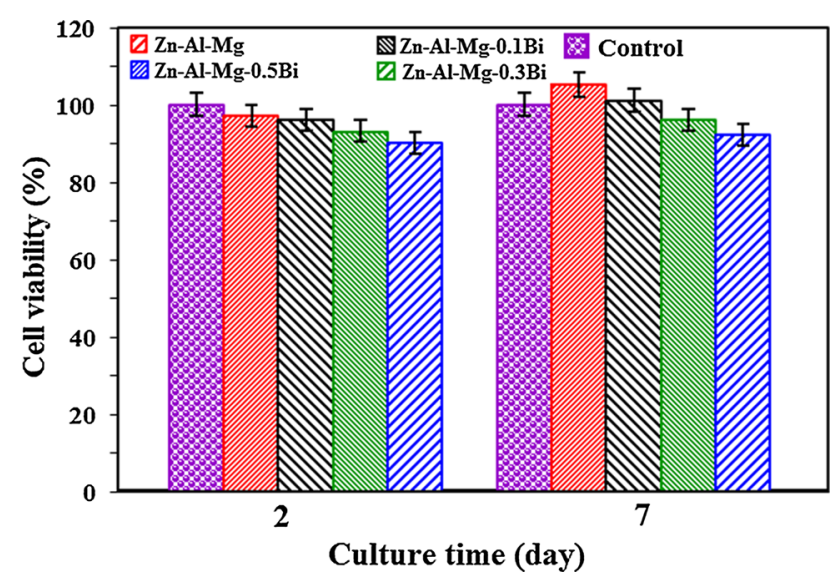

Fig. 10 Cell viability of MC3T3-E1 cells after incubation in of $\mathrm{Zn}-$ $0.5 \mathrm{Al}-0.5 \mathrm{Mg}$ and $\mathrm{Zn}-0.5 \mathrm{Al}-0.5 \mathrm{Mg}-x \mathrm{Bi}(x=0.1,0.3$ and $0.5 \mathrm{wt} \%)$ for 2 and 7 days. Error bars show standard deviation for $n=3$ samples

and $\mathrm{Bi}$ ) after immersion in minimum essential medium (MEM) with $10 \%$ fetal bovine serum, and their results exhibited no significant difference between control group and $\mathrm{Zr}-1 \mathrm{Bi}$ alloys (cell viability of $93 \%$ ). This is an indication that the $\mathrm{Zr}-1 \mathrm{Bi}$ alloy is safe as an implantable material. Gao et al. [29] evaluated the cytotoxicity of bismuth oxychloride $(\mathrm{BiOCl})$ nanosheets, and they indicated that $\mathrm{BiOCl}$ had no cytotoxicity at low concentrations. Sanderson et al. [30] reported no toxic effects of $\mathrm{Bi}$ shot embedded in the breast muscles of game-farm mallards. However, further investigations, including in vivo biocompatibility evaluations [31], are required to further understand and verify the biocompatibility of the zinc alloy containing Bi.

\section{Conclusions}

In this study, thermal and microstructural characteristics, mechanical properties, in vitro degradation behavior and cytotoxicity of $\mathrm{Zn}-0.5 \mathrm{Al}-0.5 \mathrm{Mg}$ and $\mathrm{Zn}-0.5 \mathrm{Al}-0.5 \mathrm{Mg}-$ $x \mathrm{Bi}(0.1 \leq \mathrm{x} \leq 0.5)$ alloys were investigated. The structure of $\mathrm{Zn}-0.5 \mathrm{Al}-0.5 \mathrm{Mg}$ alloy consists of $\mathrm{FCC}-\mathrm{Al}+\mathrm{HCP}-$ $\mathrm{Zn}+\mathrm{Mg}_{2}(\mathrm{Zn}, \mathrm{Al})_{11}$ at room temperature, while an additional phase of $\alpha-\mathrm{Mg}_{3} \mathrm{Bi}_{2}$ is detected in the quaternary $\mathrm{Zn}$ $0.5 \mathrm{Al}-0.5 \mathrm{Mg}-x \mathrm{Bi}(x=0.1,0.3$ and $0.5 \mathrm{wt} \%)$ alloy. The tensile strength, elongation and hardness were slightly increased after addition of $\mathrm{Bi}$ to the ternary $\mathrm{Zn}-\mathrm{Al}-\mathrm{Mg}$ alloy. The corrosion rates of the $\mathrm{Zn}-\mathrm{Al}-\mathrm{Mg}$ alloys are slightly lower than those of the $\mathrm{Zn}-\mathrm{Al}-\mathrm{Mg}-\mathrm{Bi}$ alloys due to the less galvanic coupling occurring between $\mathrm{Zn}$ and $\alpha$ $\mathrm{Mg}_{3} \mathrm{Bi}_{2}$ secondary phases. In vitro cytotoxicity test results indicate that $\mathrm{Zn}-\mathrm{Al}-\mathrm{Mg}-\mathrm{Bi}$ alloys have a more toxic effect on MC3T3-E1 cells compared to $\mathrm{Zn}-\mathrm{Al}-\mathrm{Mg}$ alloy. Thus, further investigation in an in vivo environment will help further the present study to develop $\mathrm{Zn}-\mathrm{Al}-\mathrm{Mg}$-based alloy for biodegradable metal implants.

Acknowledgements The authors thank the Malaysian Ministry of Higher Education (MOHE) and Universiti Teknologi Malaysia for providing the facilities for this research.

\section{References}

[1] S. Zhang, X. Zhang, C. Zhao, Acta Biomater. 6, 626 (2010)

[2] X.N. Gu, Y.F. Zheng, Front. Mater. Sci. China 4, 111 (2010)

[3] Y. Xin, T. Hub, P.K. Chu, Acta Biomater. 7, 1452 (2011)

[4] C. Yao, Z. Wang, S.L. Tay, T. Zhu, W. Gao, J. Alloys Compd. 602, 101 (2014)

[5] X. Liu, J. Sun, K. Qiu, Y. Yang, Z. Pu, L. Li, Y. Zheng, J. Alloys Compd. 664, 444 (2016) 
[6] M.S. Dambatta, S. Izman, D. Kurniawan, S. Farahany, B. Yahaya, H. Hermawan, Mater. Des. 85, 431 (2015)

[7] L. Tan, X. Yu, P. Wan, K. Yang, J. Mater. Sci. Technol. 29, 503 (2013)

[8] D. Vojtech, J. Kubásek, J. Šerák, P. Novák, Acta Biomater. 7, 3515 (2011)

[9] J. Kubásek, D. Vojtěch, E. Jablonská, I. Pospíšilová, J. Lipov, T. Ruml, Mater. Sci. Eng., C 58, 24 (2016)

[10] E. Mostaed, M. Sikora-Jasinsk, A. Mostaed, S. Loffredo, A.G. Demir, B. Previtali, D. Mantovani, R. Beanland, M. Vedani, J. Mech. Behav. Biomed. Mater. 60, 581 (2016)

[11] J. Luo, H. Yan, N. Zheng, R.S. Chen, Acta Metall. Sin. (Engl. Lett.) 29, 205 (2016)

[12] B. Homayun, A. Afshar, J. Alloys Compd. 607, 1 (2014)

[13] L.L. Soon, H. Zuhailawati, I. Suhaina, B.K. Dhindaw, Acta Metall. Sin. (Engl. Lett.) 29, 464 (2016)

[14] F. Witte, V. Kaese, H. Haferkamp, Biomaterials 26, 3557-3563 (2005)

[15] E. Willbold, A.A. Kaya, R.A. Kaya, F. Beckmann, F. Witte, Mater. Sci. Eng., B 176, 1835 (2011)

[16] H.Y. Tok, E. Hamzah, H.R. Bakhsheshi-Rad, J. Alloys Compd. 640, 335 (2015)

[17] FACTSAGE, Integrated Thermodynamic Databank System, University of Montreal, Quebec, Canada, 2001

[18] H.R. Bakhsheshi-Rad, E. Hamzah, A.F. Ismail, Z. Sharer, M.R. Abdul-Kadir, J. Alloys Compd. 648, 1067 (2015)
[19] T. Kokubo, H. Takadama, Biomaterials 27, 2907 (2006)

[20] ASTM E8 / E8M-08, Standard Test Methods for Tension Testing of Metallic Materials, ASTM International, West Conshohocken (2008). http://www.astm.org

[21] E. Willbold, X. Gu, D. Albert, K. Kalla, K. Bobe, M. Brauneis, C. Janning, J. Nellesen, W. Czayka, W. Tillmann, Y. Zheng, F. Witte, Acta Biomater. 11, 554 (2015)

[22] H. Liang, S.L. Chen, Y.A. Chang, Metall. Mater. Trans. A 28, 1725 (1997)

[23] X. Liu, J. Sun, Y. Yang, F. Zhou, Z. Pu, L. Li, Y. Zheng, Mater. Lett. 162, 242 (2016)

[24] T. Lei, W. Tang, S.H. Cai, Corros. Sci. 54, 270 (2012)

[25] P. Yin, N. Li, T. Lei, L. Liu, C. Ouyang, J. Mater. Sci. Mater. Med. 24, 1365 (2013)

[26] Y. Chen, Z. Xu, C. Smith, J. Sankar, Acta Biomater. 10, 4561 (2014)

[27] H. Li, H. Yang, Y. Zheng, F. Zhou, K. Qiu, X. Wang, Mater. Des. 83, 95 (2015)

[28] F.Y. Zhou, K.J. Qiu, H.F. Li, T. Huang, B.L. Wang, L. Li, Y.F. Zheng, Acta Biomater. 9, 9578 (2013)

[29] X. Gao, X. Zhang, Y. Wang, Y. Wang, S. Peng, C. Fan, Food Chem. Toxicol. 80, 52 (2015)

[30] G.C. Sanderson, W.L. Anderson, C.L. Foley, L.M. Skowron, J.D. Brawn, J.W. Seets, Ill. Nat. Hist. Surv. Bull. 35, 185 (1997)

[31] M.R. Bafandeh, R. Gharahkhani, M.H. Fathi, Fabrication, J. Adv. Mater. Process 4, 3-13 (2016) 